\title{
Full transcriptome analysis of Chinese Hamster Ovary cell lines producing a dynamic range of Coagulation Factor VIII
}

\author{
Christian S Kaas ${ }^{1,2 *}$, Claus Kristensen ${ }^{1}$, Jens J Hansen ${ }^{1}$, Gert Bolt ${ }^{1}$, Mikael R Andersen² \\ From 23rd European Society for Animal Cell Technology (ESACT) Meeting: Better Cells for Better Health \\ Lille, France. 23-26 June 2013
}

\section{Background and novelty}

Coagulation Factor VIII (FVIII) is an essential cofactor in the blood coagulation cascade. Inability to produce functional FVIII results in haemophilia A which can be treated with recombinant FVIII [1]. Chinese Hamster Ovary (CHO) cells are the most used cell line for producing complex biopharmaceuticals due to its ability to perform complex post-translational modifications. When mammalian cells overexpress a protein like FVIII they will adapt by regulating various proteins and pathways to support synthesis/production of this protein. Yields of FVIII produced in $\mathrm{CHO}$ are low and for this reason a greater understanding of what constitute a high producing cell line is desired. In this study a full transcriptome analysis was undertaken in order to analyze the differences between high and low producers of FVIII

\section{Experimental approach}

The FVIII gene was introduced into CHO-DUKX-B11 cells and a stable pool was generated by selection with MTX. A number of subclones were analysed and 3 high producing clones, 3 medium producers and 3 low $(\sim 0)$ producer clones were isolated. These 9 clones were grown in shake flasks in batch culture. During the cultivation essential metabolites were monitored as well as cell number and viability. RNA was extracted after 48 hours of cultivation and sequenced using the Illumina HiSeq system. Reads were processed and aligned to the CHO-K1 genome [2] using Tophat2 and expression levels were deduced using htseq

\footnotetext{
* Correspondence: csrk@novonordisk.com

${ }^{1}$ Department of Mammalian cell technology, Novo Nordisk A/S, Maaloev, 2760, Denmark

Full list of author information is available at the end of the article
}

\section{Results and discussion}

Experiments showed that 48 hours into the cultivation cells were seen to grow in the exponential phase in media still containing sufficiently high amounts of glutamine and low amounts of lactate. Furthermore, a significant difference in FVIII levels was detected at this time in the media of cells from the different groups and for this reason this time point was chosen for extraction of RNA. 1677 genes were found to be differentially expressed in high vs non-producing clones. Among these, genes involved in oxidative stress were seen to be enriched $\left(\mathrm{p}=1.74 \times 10^{-6}\right)$. This finding is strengthened by the work by Malhotra et al [3] showing that $\mathrm{CHO}$ cell lines activate the oxidative stress response when producing FVIII, which might induce apoptosis. The non-FVIII-producing clones were seen to express predominantly truncated FVIII-DHFR mRNAs (Figure 1) explaining the phenotype for growth in media containing MTX selection but no functional FVIII expressed. Further analyses are ongoing.

\footnotetext{
Authors' details

'Department of Mammalian cell technology, Novo Nordisk A/S, Maaloev, 2760, Denmark. ${ }^{2}$ Center for Microbial Biotechnology, Technical University of Denmark, Kgs Lyngby, 2800, Denmark.
}

Published: 4 December 2013

References

1. Thim L, Vandahl B, Karlsson J, Klausen NK, Pedersen J, Krogh TN, Kjalke M, Petersen JM, Johnsen LB, Bolt G, Nørby PL, Steenstrup TD: Purification and characterization of a new recombinant factor VIII (N8). Haemophilia. The official journal of the World Federation of Hemophilia 2010, 16:349-359.

2. Xu X, Nagarajan H, Lewis NE, Pan S, Cai Z, Liu X, Chen W, Xie M, Wang W, Hammond S, Andersen MR, Neff N, Passarelli B, Koh W, Fan HC, Wang J, Gui Y, Lee KH, Betenbaugh MJ, Quake SR, Famili I, Palsson BO, Wang J: The genomic sequence of the Chinese hamster ovary (CHO)-K1 cell line. Nature biotechnol 2011, 29:735-741. 


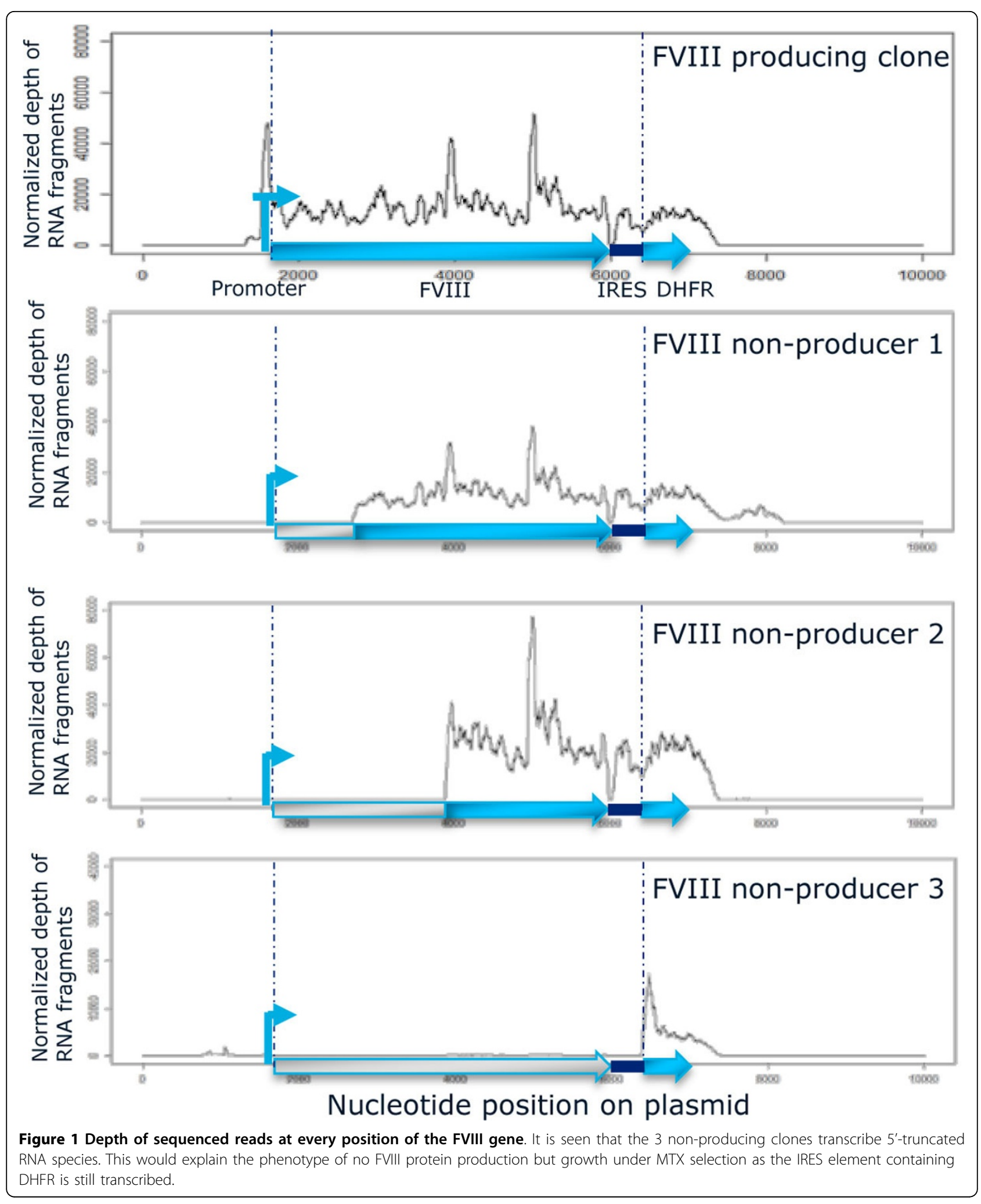


3. Malhotra JD, Miao H, Zhang K, Wolfson A, Pennathur S, Pipe SW,

Kaufman RJ: Antioxidants reduce endoplasmic reticulum stress and improve protein secretion. PNAS 2008, 105:18525-18530.

doi:10.1186/1753-6561-7-S6-P56

Cite this article as: Kaas et al:: Full transcriptome analysis of Chinese Hamster Ovary cell lines producing a dynamic range of Coagulation Factor VIII. BMC Proceedings 2013 7(Suppl 6):P56.

Submit your next manuscript to BioMed Central and take full advantage of:

- Convenient online submission

- Thorough peer review

- No space constraints or color figure charges

- Immediate publication on acceptance

- Inclusion in PubMed, CAS, Scopus and Google Scholar

- Research which is freely available for redistribution

Submit your manuscript at www.biomedcentral.com/submit
Ciomed Central 